\title{
PROMOTION OF THE RURAL POOR IN INDIA ${ }^{1}$
}

\author{
By Theodor BergmanN
}

\section{Introduction}

The green revolution was not the anticipated success ${ }^{2}$. The achievements were quite limited regarding regions, crops, participating social strata. The great majority of small cultivators was not mobilized and neither joined the efforts nor shared the fruits of the new fertilizer-seed technology $y^{3}$. Ten years after the start of the green revolution, the Indian farming sector continues to depend entirely upon the vagaries of climate and weather, upon the annual variation of harvests and upon the ongoing race between agricultural production and human reproduction. The government of Indira Gandhi has recognized the political and economic potential of this majority of the farming population. In 1970, a new initiative was conceived: the establishment of agencies assisting and promoting the poorest strata, beginning with pilot projects with the intention to enlarge the net of services to cover the whole country in case of success ${ }^{3 a}$.

\section{Brief description of the situation}

Since 75 years, the population grows without interruption and with acceleration; the growth rate increased from 0.4 percent for the decade $1901-11$ to 24.7 p.c. in 1961-71. The farming population has grown from 157 millions in 1901 to 378 millions in 1971 due to the fact, that there are hardly any alternatives in the other sectors. The man-land-ratio was narrowed with all concomitant effects: fragmentation of land, decreasing size of operational units, increase of landless labourers and marginal smallholders, deteriorated tenancy conditions, rise of landrent. The agrarian sector is called to produce more, annually for an additional 14 million mouthes or 3 percent more only to maintain the actual level of nutrition, which is already insufficient in quality and quantity.

Agricultural crop production has grown since 1950 to $1972 / 73$ by 82 p.c., while population grew by 58 p.c. With interruptions and setbacks, food production finally gained a considerable advantage against population growth. In this global

\footnotetext{
1 This is a very abridged version of a research report, published in English by the Institut für ausländische Landwirtschaft, Büsgenweg 2, 3400 Göttingen and available through the following publisher: SSIP-Verlag, D. Breitenbach, Memeler Str. 50, D-6600 Saarbrücken 3.

Critical remarks about the first, German version of the report were offered by Peter von Blanckenburg, Berlin, Guy Hunter, London, Thomas Paulini, Stuttgart-Hohenheim, and a few other colleagues. These and the cooperation of Dieter Eitel, Stuttgart-Hohenheim, are gratefully acknowledged. The responsibility for all opinions and possible errors lies with the author only.

2 A critical assessment of the green revolution is given in Theodor Bergmann, Reforme agraire et revolution verte - le cas de l'Inde In: Economie Rurale, Paris, No. 88, avril-juin 1971, pp. 15-25. See also T. J. Byres, The dialectic of India's green revolution. In: South Asian Review, London, 5, 2, January 1972 .

3 That is the more modest denomination now given e.g. by Peter von Blanckenburg, Polarisierung oder leistungsbedingte Differenzierung. Zur Frage der Nutznießer der Saatgut-Dünger-Technologie in dichtbesiedelten Entwicklungsländern. In: Zeitschrift für ausländische Landwirtschaft, 13, 1, 1974, pp. 57-79.

3a The author had the privilege of a research grant of the Deutsche Forschungsgemeinschaft and of a research tour in 6 of the 22 federal states of India in spring 1975. The findings of his field observations and of an analysis of research publications and statistics are presented in this paper for critical discussion.
} 
evaluation, some crops had a very good record, others are lagging. Wheat has not produced essentially higher yields than rice, which would justify the frequently used word of miracle wheat and high-yielding varieties. The annual variations continue to destabilize the regular flow of food procurement. The dependence upon nature is still stronger than the effect of the green revolution.

The central government has not neglected the farming sector in the allocation of plan outlays. In spite of these allocations and the efforts of Indian extension workers and foreign experts, development is and remains slow. This suggests the existence and activity of immanent factors of depression, e.g.:

1. The secular drain of the rural surplus by colonial government and British planters,

2. the continued drain by feudal landlords, who are more given to conspicuous consumption than to productive investment,

3. the heavy impact of relative agrarian overpopulation, of a growing agricultural population, that has to be fed and maintained without being able to raise the total productivity.

According to the agricultural census $1971^{4}$, the tiny operational units have increased by 20 millions since 1961, while the cultivated acreage was augmented by 29 million hectares. More than 50 p.c. of all "holdings" dispose of less than 1 ha and 9 p.c. of the entire cultivated acreage. The average unit cultivates 2.3 ha. Unter usual conditions, this acreage can neither employ nor feed an Indian family. High agrarian density and low productivity of all production factors have the effect that the rural population, too, is intensively affected by poverty, distress and destitution. The urban poor are largely the spillover from massive rural poverty ${ }^{5}$.

All attempts to reform agrarian structure and the land tenure systems have been abortive, the legal agrarian reform, reform by persuasion and prayer of Vinoba Bhave, the violent attempt, organized by the communist party in 1949 in Telengana. The changes in land ownership were very small. Upto 1973, government has distributed 5.9 millions ha of uncultivated waste or fallow, crownland, and 937,000 ha of land expropriated according to land reform laws.

The strategy of the green revolution in fact implied the desire to finish with all structural reforms, which supposedly trouble production and frighten the investors, and to substitute them by a big leap forward of production. This would finally and once for all prove, that the social framework is wide enough for substantial economic growth ${ }^{6}$.

\footnotetext{
4 Generally, the agricultural census data have to be commented upon with great caution due to political influence exercised on data collection. But, the figures might reflect the heavy and growing fragmentation of holdings. See Naidu, I. J. (ed.), All-India report on agricultural census 1970-71, New Delhi, 1975.

5 Cf. V. M. Dandekar and Nilakantha Rath, Poverty in India, Poona, 1971, pp. 16/17.

6 This view is expressed by W. A. Lewis, Die Theorie des wirtschaftlichen Wachstums, Tübingen, 1956, but strongly opposed by J. K. Galbraith, Gesellschaft im Ưberfluß, München, 1963.
} 


\section{The new development agencies}

\subsection{The organizational build-up}

After the limited success of the green revolution, the government in 1971 established a new line of "administration" and of assistance in selected districts. Small Farmers Development Agencies (SFDA) were formed in 46 districts. Marginal Farmers and Landless Labourers Development Agencies (MFALDA) were established in 41 districts ${ }^{7}$. These new agencies ought to limit themselves to assist these two marginal or marginalized groups, but through the already existing institutions. The construction of an autonomous large organization was explicitly rejected.

The first tasks were to delimit and identify the beneficiary groups, to analyze possible actions of assistance and to analyze activities and functionality of the existing institutions. Suggested activities should to the utmost be executed by these institutions.

The role ascribed to the new agencies was that of promotor and catalyst, which might give an initial ignition or an additional fuel injection accelerating the rolling motor, but not the role of executor proper.

The districts and regions were selected after certain criteria, which should have assured maximum success with minimum inputs:

a) substantial numbers of smallholders worthy of promotion

b) growth potential of production, availability of underground and surface water for irrigation

c) intensive promotion programs under implementation or in the stage of planning

d) cooperative credit structure

e) access to urban markets.

A supervising committee was formed with the representatives of the various branches of administration, leaving out the representatives of the concerned strata.

\subsection{The results}

The total activities of both agencies - for small, potentially viable farmers and for marginal farmers and landless labourers - until June 1975 are summed up in table 1. - The 46 agencies of the first type - SFDA - have identified 3.3 million persons as eligible; thereof, 1.8 millions were brought into primary cooperatives. For their promotion, 370 million Rs. were budgeted during the total period since the start, but 381 millions were actually spent. With this amount, credits of different duration (short, medium, long term) of 1,048 million Rs. were mobilized, i.e. less than three times the amount offered initially by the administration. This perhaps sheds some light on the hesitations of traditional credit institutions, even cooperative ones, to give loans to small cultivators. This slowness and reluctance is due to missing creditworthiness of the cultivators, but also to institutional restrictions and barriers. 11 p.c. only of all credit was given by commercial banks, the rest by cooperatives.

7 In 1970, the country was organized in 343 districts. 
Table 1: Progress of special programs for the weaker rural sections up to end of June 1975

\begin{tabular}{|c|c|c|c|c|}
\hline & \multicolumn{2}{|c|}{ SF D A } & \multicolumn{2}{|c|}{ M F A L } \\
\hline & \multicolumn{4}{|c|}{ up to end of June } \\
\hline & 1972 & 1975 & 1972 & 1975 \\
\hline 1. Projects & 46 & 46 & 41 & 41 \\
\hline $\begin{array}{l}\text { 2. Identified small farmers } \\
\text { and labourers* }(1,000)\end{array}$ & 1,684 & 3,290 & 788 & 1,470 \\
\hline $\begin{array}{l}\text { thereof brought into } \\
\text { cooperatives }(1,000)\end{array}$ & 818 & 1,790 & 194 & 610 \\
\hline $\begin{array}{l}\text { 3. Finance released since } \\
\text { inception ( } \mathrm{mln} \text {. Rs.) }\end{array}$ & 123.6 & 370 & 73.8 & 246 \\
\hline $\begin{array}{l}\text { thereof actually utilised } \\
\text { (mln. Rs.) }\end{array}$ & 65.9 & $381^{* * *}$ & 29.2 & 235 \\
\hline $\begin{array}{l}\text { 4. Shortterm production loans } \\
\text { issued during the year } \\
\text { (mln. Rs.) }\end{array}$ & & & & \\
\hline by cooperatives & 122.3 & 302.0 & 9.2 & 29.6 \\
\hline by commercial banks & - & 10.3 & - & 2.4 \\
\hline 5. Investment loans (mln. Rs.) & & & & \\
\hline by cooperatives & 148.6 & 629.2 & 10.4 & 131.4 \\
\hline by commercial banks & 3.8 & 106.4 & 2.8 & 79.2 \\
\hline 6. Physical results & & & & \\
\hline Tubewells/dugwells & 34,146 & 136,782 & 2,573 & 24,254 \\
\hline Pumpsets installed & 8,081 & 36,195 & 1,279 & 9,111 \\
\hline Milk cattle units set up & 11,047 & 66,130 & 5,776 & 54,735 \\
\hline Poultry units & 2,113 & 5,883 & 2,583 & 3,770 \\
\hline Rural artisans trained & 600 & 8,553 & 463 & 4,923 \\
\hline $\begin{array}{l}\text { Labourers employed under } \\
\text { rural works }\end{array}$ & 8,476 & 92,739 & 12,756 & 216,638 \\
\hline
\end{tabular}

* Persons identified as eligible for the programs.

* Number of animals purchased is not given; in most cases probably one milking animal. For poultry units

mostly 150 one day chicken.
$* *$ Expenditure exceeds funds; agencies could utilize funds received under "other sources".

Source: Report on currency and finance, 1974-1975, I and II. Bombay, 1975.

136,800 wells were dug, 36,200 pumpsets installed. 66,000 "dairy units" were established, generally with one milking cow or buffalo per unit. The programs for professional training and public works have been no great success and have benefitted a very small portion of the eligible population.

The figures for the second type of agencies - MFALDA - established in 41 districts, are of the same dimension. 1,470,000 persons were identified and 610,000 
of these enrolled into cooperatives. 246 million Rs. were budgeted and 235 millions utilized. The mobilizing effect was even weaker; loans for 242.5 millions were issued, for the reason mentioned above, which is valid for all banking institutions, be they commercial or cooperative.

Regarding irrigation, the results were more limited, while credit for purchase of cattle was largely exhausted. This group has not enough land to utilize irrigation economically. The same is clearly true for milk cattle. But, pasture is available in the village commons, overgrazed and hardly maintained. In public works, 216,000 workers were employed. But, the duration of their employment remains unknown.

The total annual expenses for both agencies represent 0.24 p.c. of the central budget $^{8}$. Of the total agricultural population (according to the census of 1971) 3.2 p.c. were identified upto June 1975 , i.e. their eligibility for promotion was stated. Promotion itself - as referred in table 1 - can imply transfer to another institution for further care or assistance. It is unknown, how many cultivators were in fact materially assisted by any of the programs. If the total expenses are divided by the number of eligible people (identified by the agencies), 128 Rs. were available for each person. Furthermore, the share of the funds is unknown, which was versed to the institutions to enable them to promote the eligible groups, as also the costs of salaries and administration. Taken as a whole, the total effort might appear impressive, but the effect of about 100 Rs. per beneficiary cannot be very strong. Therefore, in macro-economic terms and as an impulse for production, the available funds don't change the situation very much. Promotion effect, socially equitable and politically profitable distribution cannot be combined, if funds and resources are scarce.

In such an evaluation, by necessity global, the question is left aside, whether and to which extent the support has really benefitted the eligible group or which part was diverted towards other, non-eligible social groups. Laxinarayan and Gupta9 found 20 to 33 p.c. of the beneficiaries as not eligible. The experience with other Indian programs, as also research in other countries, indicates, that many programs of public subsidies have an immanent bias towards the wealthier strata ${ }^{10}$. There are several reasons for that situation, e.g.

1. Pressure upon extension workers to show success, which compels them to approach the most capable and innovative farmers.

2. Professional training and social origin of the extension workers ${ }^{11}$.

3. Ability of large landholders to find public funds and advantage in information.

4. Low salary, economic dependence of extension workers and, vice versa, economic capacity of landlords to influence administrators.

8 In this calculation, central outlays for development in the five-year plan and the corresponding outlays of the states were omitted.

9 H. Laxminarayan, SFDA-programme - a note. In: Economic and Political Weekly, Bombay, VIII, 17, April 28, 1973; same author: SFDA-programme. A case study of Ambala. ARC-News, Bombay, AprilJune 1973; and D. P. Gupta, SFDA-programme in Amritsar-Ferozepur (Punjab), an evaluation of progress and problems. Agricultural Economic Research Centre, University of Delhi, I and II (stenciled).

10 Sarupria (1975) summarizes: "It is a common knowledge, that the cooperatives, community development schemes, and panchayats have generally failed in their primary objective of assisting the weaker sections of the population, not to speak of the fact that they did not materially improve farm
production." (p. 87) Shantilal Sarupria, Approach to regional development in India. In: Peter Meyerproduction." (p. 87) Shantilal Sarupria, Approach to regional development in India. In: Peter Meyerpp. 44-49. Official figures for the US show, that the small group of the most wealthy farmers collects the lion's part of government payments. (See: Who will control US-agriculture. University of Illinois, Urbana, 1972).

11 In India, social origin is a strong barrier against communication. Even in our days, there are extension workers of high caste trying to avoid personal contact and discussion with Harijans, if possible. 


\subsection{Immanent barriers}

One serious problem is the delimitation of the eligible social strata. The basic rules of the central government are modified by the states and adapted to the natural conditions of the regions. On the state level, the influence of the big landowners is more direct and stronger, thus rising their chance to achieve modifications in their interest. The more administration gets down to the local level, where directives and rules have to be implemented, the stronger becomes the influence of the powers that be. All the measures of circumvention known from agrarian reform laws are utilized here, too. This is frequently described in official and non-official literature ${ }^{12}$.

The delimitation of the eligible group is not only a technical and administrative problem. It is rather a basic issue of farm policies in social systems with individual holdings. Every method of demarcation creates cases, where people feel disadvantaged, and offers room for biassed decisions. But first of all, a ceiling of eligibility for financial assistance shows, that the unity of the farming community is a fiction. Just that fiction and taboo was very useful and profitable for the wealthy strata of the rural population. Therefore, a clear-cut and efficient delimitation of the eligible clientele would provoke the entrenched resistance of the upper strata.

Protection against misuse by rich groups and persons is hardly feasible the administrative way, since the public service is largely recruited from the same strata. Originally, it had been suggested to put the new agencies under the control of committees of the rural poor to be formed at the same time. On the road to implementation, such radical ideas are frequently diluted or changed into the opposite direction. Cheema ${ }^{13}$ has called for the formation of special organizations of the lower rural strata for advice, control and pressure against the new agencies, if need be.

The activities are directed towards the individual farming unit. Due to its tiny size, the share of administrative costs must be considerable, even prohibitve sometimes. Some programs are hardly applicable due to extreme fragmentation and insecurity of the tenant's status, e.g. irrigation, one of the most important programs to boost production. A joint irrigation system for several smallholders would be economic, but is barred by fragmentation. Similar problems bar the expansion of milk production.

The system of land tenure (tiny units, fragmentation, tenancy, share-cropping) poses objective difficulties - beyond the will of the agencies - to the promotional programs. Urgent needs induce numerous beneficiaries to divert the small subsidies into consumption, or into repayment of burdensome debts with the local usurer etc. instead of productive investment.

The new agencies have no directive power against the rooted, established institutions, through which their programs have to be implemented, except persuasion, request and payment. Control of implementation is unfeasible.

12 Cf. e.g. Report of the All-India rural credit review committee. Bombay, 1969, p. 589.

$13 \mathrm{~A}$. S. Cheema, Indian agriculture in retrospect and prospects. Symposium on agricultural development, Ludhiana, India, 1975 (stenciled). 


\subsection{New proposals}

Lively criticism and visible failures of the new structure have led to a new concept, which aims at integration of all special programs (arid zones, drought prone areas, backward classes etc.) with the two agencies. The argument is put forward, that essentially or very frequently unfavorable natural conditions cause an economic drawback for vast masses; therefore, massive rural poverty is endemic in arid zones and similar regions. A merger of the numerous administrative lines would streamline bureaucracy, abolish administrative duplication and would open up a comprehensive, integrated approach to the entire problem, hitherto barred by the multiplication of specialists.

This argument might be doubted. But, more important: such a new concept would push aside the socio-political aspect of promotion of the needy in favour of increased production, which again would become the main aim. The line of arguing leading to the new concept ignores the socio-economic constraints, that just have barred a rapid growth of production.

\section{Basic issues of a strategy of agrarian development}

Analyses, evaluations and recommendations of agricultural economists in Europe and northern America frequently start from concepts, indicators, judgments, that perhaps are applicable in highly industrialized societies and in systems of capitalist economy. In reality, however, the instruments of research and of agrarian policies are tied to their economic system and to a specific phase of development. In other systems and development phases, they might assume entirely different content and importance.

\subsection{Innovation and size of holding}

In now industrialized societies, bio-technical progress and innovation were largely size-neutral, i.e. they were applicable and could be adopted by holdings of all sizes without economic differentiation. But, new transport technologies favour the large producers, who both purchase and utilize more fertilizers, seeds, feedstuff and sell more milk, grain etc. The differences between small and large landholders grow so much, that even cooperatives cannot level them off and would harm their own economy, if they tried to do so. Subsidies paid according to fertilizer input or output marketed emphasize the effect of bio-technical progress on structural change. The smaller the operational holding and its monetary turnover, the more it becomes evident, that bio-technical innovation remains technically divisible in small units or quantities, but goes economically beyond the financial capacity of the small and marginal cultivator. Blanckenburgisa believes that the innova-

13a Cf. Note 3.

$14 \mathrm{~F}$. Kuhnen, Land tenure and agarian reform with particular reference to social and employment prospects. Report on the Asian regional seminar on the contribution of rural institutions to rural development. ILO, Geneva, pp. 32-47 (stenciled). Zubeida Manzoor Ahmad, The social and economic implications of the green revolution in Asia. In: International Labour Review, Geneva, 105, 1, January 1972, pp. 9-34. V. S. Vyas and N. S. Jodha, Contribution of dairying to rural economy with particular reference to small and marginal farmers. In: ARC-News, Bombay, 11, 4 January-March 1974 , pp. 67-71. 
tions offered by the green revolution are adopted by large and small farmers. Kuhnen, Ahmad, Vyas and Jodha ${ }^{14}$ oppose this line and find that these innovations are not size-neutral and accessible to everybody. - Our conclusion is: Even if some small cultivators adopt the innovations, the great majority remains untouched and excluded. Apparently, the reasons are rather financial and economic ones, not mental ability, management ability or harder work.

\subsection{Equality and inequality as factors of economic mobilization}

One current of Indian economic thinking and action views growing inequality as a necessary, even desirable effect of economic take-off, also as psychological incentive to work harder. This line is probably supported by the open opponents of Mrs. Gandhi in the Congress and by the conservative parties. The other line is afraid, lest growing inequality, particularly under conditions of mass poverty, might become a negative stimulus and would contribute to socio-political unrest and instability. If the masses of the poor lose the hope to find employment by normal ways, to feed and maintain themselves by work and income, if they realize that the gap between rich and poor continues to grow, that they do not share the fruits of development, their work output diminishes and alienation grows.

It seems to us unrealistic to view inequality as motor of development and the desire of more equality as factor of stagnation and to argue that personal effort and incentives are missing, if India is compared with China. Perhaps, the income differential in India is one of the widest in the world; inequality and conspicuous consumption are shown as open and visible provocation. The economy is close to stagnation. China, on the other hand, aims at equality and has continued its economic build-up after the setback of the cultural revolution. Kropp ${ }^{15}$ recognizes the distinction between economies in different development stages:

"In difference from all experiences of developed countries, the growing differentiation of incomes does not lead to increased capital formation, investment activities, creation of additional employment and growing production in agriculture, rather to strengthened dependence, indebtedness and bondage and increase of the population below the poverty threshold." (p. 484)

Myrdal16 understands the fight for equality as prerequisite of economic growth in the third world:

"First, the usual argument that inequality of income is a condition for saving has much less bearing on conditions in underdeveloped countries, where landlords and other rich people are known to squander their incomes for conspicuous consumption and conspicuous investment, and sometimes, particularly (but not only) in Latin America, in capital flight.

Second, since large masses of people in underdeveloped countries suffer from undernutrition, malnutrition and other serious defects in their levels of living, in particular lack of elementary health and educational facilities, extremely bad housing conditions and sanitation, and since this impairs their willingness and ability to work and to work intensively, this holds down

15 Eberhard W. Kropp, Armut und Unterbeschäftigung im ländlichen Indien und Ansätze zu ihrer Beseitigung. In: Internationales Asienforum, München, 5, 4, 1974, S. 480-498.

16 G. Myrdal, The challenge of world poverty. London, 1970. 
production. This implies that measures to raise income levels for the masses of people would raise productivity.

Third, social inequality is tied to economic inequality in a mutual relationship, each being both cause and effect of the other. Greater economic equality would undoubtedly tend to lead to greater social equality. As social inequality is quite generally detrimental to development, the conclusion must be that through this mechanism also greater equality would lead to higher productivity.

Fourth, we cannot exclude from consideration that behind the quest for greater equality is the recognition of the fact that it has an independent value in terms of social justice, and that it would have wholesome effects for national integration." (p. 68)

Iyengar ${ }^{17}$ supports this line with several arguments:

"A greater equality of incomes will encourage economic growth ... It is difficult to understand, why greater income inequality is necessary for faster growth. This argument is based on the fact, that in underdeveloped countries only a small proportion of the rich families is able ... to contribute to capital formation ... (It) does not take into account conspicuous consumption where a reduction in high incomes may release resources for productive investment...

A higher level of consumption in the low-income groups as a consequence of more even income distribution would raise the productive efficiency of the labour force ... A rise in the levels of income permits ... the middle and lower middle groups to ameliorate their physical living conditions and their intellectual capacities. Ultimately, the main resource of an economy is man himself; and the satisfaction of his needs for food, clothing, medical care, education, etc. will undoubtedly increase his productive efficiency." (p. 49)

A similar conception might lie behind the discussion about fighting and abolishing poverty in India. Slogans influencing the electorate like "garibi hatao" (abolition of poverty) have appeared in official speeches and publications. Limited programs based on socio-political reasoning were planned. Several research workers believe, though, that the army of the poor and destitute has effectively grown further ${ }^{18}$. The prospects for success of the policy of abolition of poverty are not very favorable given the actual strategy and the time-span foreseen.

\subsection{Institutional change}

In India, as everywhere, opinions oppose each other vehemently and are deeply divided, whether it is necessary to change social relations and structures. Opponents of social change warn against decreased production and worsening procurement; social change might disencourage investors and would be unfair against the wealthy rural classes, compared to urban wealth. This was the view e.g. of Charan Singh.

17 N. Sreenivasa Iyengar, Economic growth and income inequality. In: Peter Meyer-Dohm (ed.), Economic and social aspects of Indian development. An A.B.O.C.S. Symposium. Tübingen - Basel Bombay, 1975, pp. 44-49.

18 See Dandekar and Rath, 1.c. Winfried v. Urff, Das Problem der Armut in der indischen Entwicklungsplanung. In: Internationales Asienforum, München 1974, 5, 5, S. 460-470 and Eberhard W. Kropp, l.c., 1974. 
Nehru, Khusro, Thorner and many others haven advocated social change ${ }^{19}$. D. R. Gadgil has taken an intermediary position and spoken of gradualist reform, of intentionally small steps on the road to change. Blanckenburg ${ }^{20}$ offers the hypothesis, that the social system slowly opens up.

This author doubts the cautious views. It should be conceded, that rapid social transformations are causing suffering to the people concerned and cause macroeconomic costs to the entire society ${ }^{21}$. The institutional and cultural barriers against social transformation are known; they are too solid. But slowing down necessary reforms bars the breakthrough from stagnation, which apparently has socio-economic reasons, and, thus, extends pains and forsaking. Furthermore, the gradualist approach rejects spectacular changes in the rural power structure. If, however, the old landlord or his representative continues to reside in the village, no oppressed and exploited cultivator would dare to believe in real change; the socio-psychological effect of liberation vanishes, that otherwise would release and accentuate the physical effort.

The dichotomous conceptualization of agrarian reform and promotion of production as a pair of contradictory notions takes a simplifying and insufficient view. Agrarian reform is the more efficient, the more it is tied to and synchronized with all available measures to raise production. Without new inputs, agrarian reform remains a half-measure, an activity to distribute pre-existing poverty and unemployment more equally, which is psychologically and socially necessary, but half-efficient only. On the other hand, just the Indian experience proves, that new inputs do not produce their entire potential under traditional production relations.

\subsection{The potential of the farming sector and strategies of mobilization}

Indian agriculture disposes of a vast production potential, hitherto unutilized, e.g. in the following spheres:

- increase of yield per ha by fertilizers, irrigation, improved seeds

- accelerated rotation by limitation of fallow, transition to double-cropping

- expansion of the cultivated acreage by wasteland reclamation

- increased yields by timely field-operations, which become possible by input of fossile energy and mechanization of heavy operations

- growth of animal production by systematic breeding, detabooization of zebu cattle, integration with field crops and improved pasture

- mobilization of unutilized rural manpower for programs to improve the rural infrastructure.

There are countries or regions with similar climatic and ecological conditions producing higher yields per ha. On the other hand, in a quantitative comparison with Japan, it has to be observed that - ceteris paribus - the diffusion of innovations and a rise of the entire productivity level takes the more time, the larger the population concerned and the acreage.

19 This issue is discussed at length by Bergmann (1967), where the references are given. Theodor Bergmann, Funktionen und Wirkungsgrenzen von Produktionsgenossenschaften in Entwicklungsländern. Frankfurt/M., 1967.

20 Cf. Blanckenburg, i.c., pp. 74-75.

21 About the social costs of revolutionary changes see Nikolai Bucharin, Okonomik der Transformationsperiode. Hamburg, 1922. 
Rising yields depend upon several factors, inter alia:

1. Radical institutional reform, abolishing the unproductive drain of the agricultural surplus

2. Industrial means of production, increasing farm production, in sufficient quantities and at prices within the reach of the cultivators

3. New sources of energy

4. Rapid machanization (connected with 2 and 3)

5. Start of manpower exodus from the farming sector.

Contradicting a wide-spread opinion, the following hypotheses are put forward.

1. Continued growth of agricultural manpower cannot increase production substantially. On the contrary, rural exodus and growth of farm production are positively correlated ${ }^{22}$.

2. For the development of farm production and for economic employment of the abundant rural manpower, industrialization is inevitable ${ }^{23}$.

\subsection{The issue of employment}

Productive employment of a growing population in the active age-groups is a key-problem of enormous dimension. A decrease of the population "active" in agriculture by one percent only implies, that 1.3 million persons have to change occupation, not necessarily their residence. Already now there is an official industrial reserve army of about 9 million unemployed and 9.8 million underemployed, working less than 14 hours per week ${ }^{24}$. Of these 19 millions and their dependants a large part live in the urban slums under subhumane conditions. In spite of some exodus, the farming sector disposes of one worker per cultivated ha, which is an anormal density of manpower. Of this workforce vast numbers are effectively employed only during short seasons, but condemned to unemployment during extended periods of each year.

Such a high density is not found anywhere in countries with plough culture and draft animals. Only in gardening agriculture, where hoe and spade are the main tools (Japan in earlier periods and parts of China) the man-land-ratio is more narrow. On the other hand, the equipment of the workforce with instruments, machines and energy is very poor, their nutrition meager, work output thus small. The input of production means per man is mince. Therefore, the factor combination is unfavorable to production growth and cannot be improved by more work input in such a way, that production would rise. It seems very likely, that nearstagnation of the farming sector and unfavorable factor-combination are correlated. This view is shared by Ishikawa ${ }^{25}$, who dealt with the contribution of additional human input to agricultural production on the basis of farm studies in India, China and Japan. He found that increased work input per ha does not increase yield per ha without simultaneous increase of certain other inputs except in rare cases. Work and other inputs, as fertilizers and water, are strongly complementary.

22 The causal nexus is not immediate, rather mediated by several links: exodus - construction of factories production and delivery of new means of production - new energy sources - production growth.

23 This generalization is not valid for all economies to the same degree. But, for very populous countries, multivarious industrial development is necessary.

24 This proves that unemployment is not caused by mechanization and utilization of capital-intensive technologies, but exists before the introduction of new techniques.

25 Shigeru Ishikawa, Economic development in Asian perspective. Tokyo, 1967. 
The vast number of workers per 100 ha has a second negative effect: capital formation and integration into a monetary economy are blocked or at least slowed down. A large share of the produce is consumed in the family. Small quantities only are available for production contribution, factor contribution and market contribution.

By intensified production, work could be distributed more evenly over time and between the seasons, and a somewhat larger number of underemployed might find employment. Growing harvests would create work opportunities in branches and services based on farming, e.g. transportation, transformation, marketing. But it can hardly be assumed that the entire actual human potential and its natural growth can be productively employed in the farming sector proper, if a minimum of development is aimed at.

\subsection{Programs of rural public works}

The programs of rural public works aim at providing employment for the rural poor. Partly, they shall improve the technical and cultural infrastructure of the countryside, partly expand the production potential of farming by reclamation of wasteland, soil conservation, irrigation. All these schemes excede the frame of individual holdings both in their technical implementation and in their benefits. Therefore, they have to be organized by public administration and to be financed by public funds. These are the essential traits of such schemes: intensive input of human labour, a small portion of total expenses only is spent on tools and material; closeness to the village of residence; wages close to the level of social security, lower than market wages; part of the remuneration is given in kind.

The quantitative results of the schemes implemented by the two agencies, mentioned above (chapter 3.2), are not very impressive. - It seems reasonable to mobilize unemployed and underemployed manpower for large-scale public works, beyond the physical or financial capacity of smallholders, the fruits of which reach also beyond these holdings. The small amounts of unutilized working-time - in each case less than one manyear - are here aggregated into larger quantities, that can produce results in a reasonable lapse of time and thus lead to an (additional) cooperative effect. Such programs are located half-way between traditional compulsory work from the time of the autarcic, self-sufficient village with nonmonetary exchange on the one hand and salaried work, paid with cash money in an economy with an open labour market. The lack of modern tools and in nutrition limit the success of such programs. Too much organization, uneven distribution of the workload and of the fruits of implemented programs are the principal drawbacks to be avoided. Too much inequality harms motivation and increases the internal tensions in the village.

\subsection{Care for the weaker sections or own activity}

The politics and programs of promotion for the economically weak sections of the rural population are based on a concept of paternalist provision. The eligible people or strata are called "weaker sections", not social strata. They need support and assistance by the authorities and are considered passive receivers, while 
the rest of society is stronger, not only in economy and politics, also in culture and intrinsic force. This approach, criticized by Atal26, is understandable as result of the vast social distance between those above and those below, unbridged by intercommunication. There is no other bridge over that abyss in caste-society than charity, voluntary social assistance. It expresses the almost unchanged consciousness and self-perception of the high castes, too.

The concept of the weaker sections, deserving promotion over an extended period and with small steps only - because the nation is poor, justifies, extends and assures the privileged positions and functions of the higher castes; they form the higher levels of a huge administrative machinery and consider it as their proper domain. This illustrates a typical mechanism of self-confirmation and internal consolidation of caste-society. The mechanism is re-enforced, because the lower castes have accepted and internalized these structures through long periods of time. This became more tolerable in the minds, not at all in real life, by the reward for humility expected according to hindu belief after re-incarnation, in later lifes. The mechanism still works in our time, but not entirely. It is one of the main factors responsible for the particular way, in which Indian administrations and institutions function. It was described and criticized frequently, also in numerous official publications and enquiry reports, that institutions established for the weaker sections prove to be biassed in favour of the wealthy, influential, and not at all needy layers. Officials favour rich and influential people, neglect the poor; the elite conquers and dominates the institutions, even those with democratic structure, and diverts the funds. Public criticism and additional controlling agencies cannot change this situation very much; at the utmost they produce gradual changes. The Report ...27 says, e.g.:

"It is now generally accepted, that the smallholders have been benefitted neither according to their numbers nor according to their needs by the various programs of rural development, implemented during the third plan. Our analysis of the performance of the cooperative movement confirms, that that is true also for the availability of institutional farm credit".

Sometimes it is proposed to change the attitudes of officials and institutions by education and different types of refresher seminars and to control government agencies and socio-technical institutions, whether they fulfill their tasks. These suggestions are as frequent as criticism. But it can be supposed, that bureaucratic control would be determined by the same basic social facts as the executive bureaucracy itself 28 .

Growing unrest and frequent movements of small cultivators, though limited to narrow regions, have provoked several proposals to direct these activities and energies in channels, where they stimulate, push, press and control the administration. Thus, so it is believed, they might create a politico-social countervailing force against the invisible influence of the old, traditional power-structures. E.g., Ahmad, Minhas, Kropp and Cheema ${ }^{29}$ demand the formation of organizations of the rural poor.

26 Yogesh Atal, Weaker sections: The sociological dimension. In: Seminar on rural development for weaker sections. Bombay, 1974 , pp. $173-178$.

27 See Report ..., 1969, 1.c.

28 See about this point Kropp (1972), 1.c., particularly p. 245.

29 Ahmad (1972), l.c.; B. S. Minhas, Rural development for weaker sections: Experience and lessons. In: Seminar on rural development for weaker sections. Bombay, 1974, p. 1-11; particularly p. 8; Kropp (1974), 1.c., pp. 497-498; Cheema (1975), 1.c., pp. 8-9. 
But, the formation or emergence of such organizations is a problem closely linked to the self-consolidation of the caste-system. To be efficient, the organizations ought to be free from their opposite numbers. This liberty and independence against established rural powers implies a provocation, a challenge of castesociety; it questions and attacks the latter's foundations proper. Autonomous organization of the lower strata is the decisive step towards a socio-psychological breakthrough of the vicious circle. Under Indian conditions, mobilization of the economic potential for take-off and political and trade-union mobilization are interdependent.

These organizations fulfill a double task in the development process. On the one hand, they formulate and represent the economic and political demands of their members and clientele - like trade-unions - against big landlords, usurers and intermediaries, nonproductive and parasitic strata. And they enforce and control the implementation of their demands, transformed into law, by the authorities. On the other hand, they promote and organize the economic activities of their members. They can also be agencies for group or mass extension, propagating and diffusing innovations and supporting their adoption. If the agricultural surplus production is redistributed by an agrarian reform, the task is to utilize this surplus for rational and productive investment. If the services to the feudal landlord are abolished, manpower should be used for land improvement, irrigation, construction of schools and roads, large-scale public works, benefitting the entire population equally. The organizations can assist the rural cooperatives or can work for their formation, where they are still missing.

The two lines of activities are interdependent in a particular manner. Neither can be followed separately. There is also a relationship, a mutual influence between economic, socio-cultural and political mobilization of the vast rural masses, that have been excluded from participation in economic development and in political decisions in their village and in their nation up to now.

\section{Conclusions}

The dimension of India'a agrarian problems and their effect on take-off are evident. Technical promotion of production is barred or slowed down by structural and institutional constraints. The new agencies for the development of small farmers and of marginal farmers and landless labourers face the same difficulties and barriers as the several established extension services. Ladejinsky ${ }^{30}$ quotes B. Venkatappiah, one of the initiators of the new agencies:

"The agency will be virtually inoperative in various sectors ... unless a number of measures are first undertaken ... in regard to land records and land reforms." (p. 767)

Even if production were intensified and if institutional framework and structure were basically changed - both activities have to be closely tied, it would not be feasible to make all marginal and small holdings viable. Vyas ${ }^{31}$ summarizes the problem of the smallholders:

30 Wolf Ladejinsky, Ironies of India's green revolution. In: Foreign Affairs, New York, 48, 4, July 1970, pp. 758-768, particularly p. 767.

31 V. S. Vyas, Economic efficiency on small farms of central Gujarat. In: Seminar on problems of small farmers, Bombay, 1968, pp. 60-75. 
"Their capacity for surplus generation was low and hence the prospects for coming out of the poverty 'trap' were practically non-existent.

The main handicap wich they face on the economic side is a palpably small land base which probably accounts for the lower productivity of other fixed factors like family labour and owned bullocks even when their availability, on per hectare basis, is higher or similar to that obtained on the medium and large farms. The second handicap is the lack of liquid resources and limited access to organized credit institutions. Due to the dearth of working capital they are unable to incur adequate costs on variable inputs such as irrigation and fertilizers which have high returns per rupee of investment. Their difficulties are compounded due to the lack of cash resource; further due to their incapacity to face market uncertainties, their crop pattern is dominated by low valued subsistence crops." (p. 70-71)

The solution to the problems of farming cannot be found in the farming sector itself, because it depends of industrial inputs for increased production and is unable to employ productively the entire manpower, hitherto dependent on it. Economic growth and employment ought to be found in the other productive sectors, which by a process of exchanges must contribute towards dissolution of the near-stagnation of agriculture. In an economy, dominated by farming, the latter cannot be promoted by large-scale allocation and redistribution of other sectors' resources. In reality, the primary sector is called and forced to offer substantial contributions. Besides industrial inputs, institutional changes are necessary to stimulate its capacity and to increase its production on a large scale. These changes, again, are only possible after political, social and cultural mobilization and organization of the masses of rural poor, that persist in lethargy until now. 
holders has grown, being this a tendency to less concentration in the size structure of agricultural activity.

The influence of the land reform on the occupational situation is far from being satisfactory. The relative scarcity of land, the maintenance of an economically efficient size of production unit and the consolidation of the existing medium size enterprises are the main reasons to explain why only one quarter of the poor and landless population has benefitted from the agrarian reform. About 270000 wage-earners and 1 Million small minifundia landholders were not reached by the redistribution of land. There is also serious evidence that since the establishment of the cooperatives the number of seasonal workers has increased. The effect on income redistribution has been also very limited. There are calculations that only between $1 \%$ and $2 \%$ of domestic income was redistributed. This would be a considerable effect, if the transference of income had been from the highest to the lowest stratum of the income pyramid. But the land reform has only distributed within a subsector and not between the different subsectors. For instance, the coastal workers, who were also before the reform a group with good earnings, have received the most productive enterprises with the greatest net surplus. To the beneficiaries in the poorest part of Peru, the Southern Sierra, have been transfered the extensive and decapitalized cattle-raising units. In this way, the agrarian reform has deepened the gap between different income groups. The development of production is closely related to the land reform. Most of the adversaries of the land reform, also in the Peruvian case, argue that the land reform provokes a decline in production and that consecuently a deficit of agricultural products arises. At the moment, there are no reliable data on this question in Peru. When analyzing the Peruvian agricultural situation it will become clear that the development of production depends on a very complicate set of factors, amongst which the redistribution of land is only one. The governments' intervention in the sector, the control of prices, the precarious credit situation of the farmers, the conditions of commerzialization and the rapidly increasing prices for agricultural inputs in the last years are some of the veriables heavily affecting the development of production. The stagnation of the Peruvian agricultural production has been visible all over the last 20 years. In recent years, it has been in part a by-product of the land reform, but above all it is the result of a heterogenous productive and social structure.

Summing up, we would say that the Peruvian agrarian reform has tackled successfully the latifundia problem. The minifundia problem is far from being solved, and at the present there are not too many chances to continue the reform program in relation to this aspect.

\section{Promotion of the rural poor in India}

\section{By Theodor BergmanN}

After a brief description of the agrarian situation and the causes of near-stagnation of farm production the paper describes a new program of the central government for the marginal rural social strata. The "green revolution" had left out these masses, which are an important economic and political factor. The new agencies 
established in 1971, however, have not been more successful than all earlier attempts to help and assist the weaker sections in the frame of the agrarian sector. The immanent barriers and the built-in bias against the poor are analyzed. Criticism has led to new proposals to merge this special social program with other, regional promotion schemes, which would even diminish the aiready weak social component. An analysis of selected basic issues of agrarian development proves, that the smallholdings are too small to adopt innovations, not creditworthy for any banking agency. Actual official economic policies are criticized. Inequality has become a negative incentive for the poor toiling masses. Institutional change is necessary, if technical innovations shall accelerate economic growth. But radical agrarian reform will be successful only in combination with industrial development. A solution of the agrarian problems inside this sector alone seems unfeasible. The paternalist approach of administration towards the "weaker sections" is integral part of the caste-system and one of the instruments for its internal consolidation. Economic mobilization of the marginal masses, however, is interlinked with sociocultural and political mobilization and autonomous organization.

Agricultural Cooperatives as an Instrument of Agricultural Policy - Experience with Cooperative Promotion of Production in Egypt

\section{By OtTFRied C. Kirsch}

The interest accorded to Egypt's agrarian reforms after 1952 has been largely due to the introduction of cooperative promotion of agricultural production. Cooperatives have been the essential executive organs of the reform policy and the cooperative movement, in return, has been greatly influenced by this fact. The latest decisions to convert the cooperative functions into functions of the Rural Development Bank are however markedly anti-cooperative and suggest that the great expectations the government had of cooperatives as instruments of agriculture policy have failed to materialise. What share the various factors - planned economy and state pricing policy, authoritarian attitudes on the part of administration and extension services, inefficient water management - had in the failure of the cooperative promotion of production is impossible to state conclusively here. Taken together, all these factors must certainly take responsibility for the failure of the cooperative policy especially in the old lands.

The development of cooperative production promotion in Egypt is a prime instance of the way in which such intervention in the decision-making latitude of the agricultural smallholder-cum-cooperative member can have unexpected results for the initiating Egyptian government, in this case, circumvention of enforced crop rotation in the old lands, production of free-market food crops to the detriment of cash crops for export and the catastrophic effect on the finances of the state. But the setbacks in the old lands and the relative successes of cooperative promotion of production in new settlements and redistributed villages are misleading those vested with decision-making powers on agriculture policy in Egypt into overrating the potential of land reclamation as a solution of Egypt's economic problems. Not by stepping up land reclamation but only by utilizing the old-land agricultural potentail the present fundamental problem of the growing dispersion 